\title{
THE METABOLISM OF NORMAL PLASMA PROTEINS AND GAMMA-MYELOMA PROTEIN IN MICE BEARING PLASMA-CELL TUMORS
}

\author{
By J. H. HUMPHREY ANd J. L. FAHEY*
}

(From the National Institute for Medical Research, Mill Hill, London, England)

(Submitted for publication March 29, 1961 ; accepted May 1, 1961)

Study of the synthesis, catabolism and nature of $\gamma$-globulin has been facilitated by the availability in mice of transplantable plasma-cell tumors, each capable of synthesizing characteristic and different forms of plasma globulin (1). Since the use of such tumors in inbred mice readily permits multiple comparable observations, a study was carried out in sufficient detail to permit evaluation of the effects of different plasma-cell tumors on the metabolism of individual serum proteins. The findings were compared with those in human multiple myeloma in which published results are few and apparently conflicting. Thus, Berson and Yalow (2) found the fractional turnover rate of a $\gamma$-myeloma protein to be approximately normal in the donor patient as well as in another patient without a serum myeloma protein. Lippincott and coworkers $(3,4)$, however, observed a rapid turnover of normal $\gamma$-globulins and $\gamma$-myeloma proteins in patients with $\gamma$-myeloma proteins. Gammaglobulin turnover was less rapid in patients with $\beta$-myeloma proteins. Neufeld (5) also noted a rapid turnover for globulins in a patient with a $\gamma$-myeloma protein.

Two tumors were selected for the present study. The plasma-cell tumor 5563 (6) produces a $\gamma$-myeloma protein that is a $\gamma$-globulin on immunoelectrophoresis and a single $6.5 \mathrm{~S}$ component on ultracentrifugal analysis. This is analagous to the $\gamma$-type myeloma proteins in man. A second mouse plasma-cell tumor, 5647 (7), however, produces a $\beta$-myeloma protein with ultracentrifugal components of 9,11 and $13 \mathrm{~S}$ and distinctive immunological properties similar to the characteristic features of beta $\left(\beta_{2 A}\right)$-type myeloma globulins in man. The serum levels of the normal $\gamma$-globulin components are reduced with the 5563 tumor, but this is less evident with the 5647 tumor.

* Present address : National Cancer Institute, Bethesda,
Purified albumin, normal $\gamma$-globulin, and 5563 $\gamma$-myeloma protein from the mouse and normal human 6.6S $\gamma$-globulin were labeled with radioiodine. The metabolic behavior of these proteins was studied in normal mice as well as in mice bearing the $\gamma$ (5563) plasma-cell tumor, the $\beta$ (5647) plasma-cell tumor or a mammary carcinoma. This last tumor produced no serum myeloma protein but was transplanted and grew in the same way as did the others and thus served as a control for the effect of the presence of neoplasm per se on the turnover of these proteins.

The $\gamma$ (5563) plasma-cell tumor has a profound effect, markedly increasing the turnover of both normal mouse $\gamma$-globulin and $5563 \gamma$-myeloma globulin. Less marked effects were noted with the $\beta$ (5647) plasma-cell tumor. Albumin turnover, however, was not altered by the tumors.

\section{MATERIALS AND METHODS}

Mice. $\mathrm{C}_{3} \mathrm{H} / \mathrm{He}$ and $\mathrm{BAlb} / \mathrm{c}$ strains were obtained through the kindness of Dr. Michael Potter, National Cancer Institute, NIH, and the lines maintained by brother-sister mating.

Tumors. Plasma-cell tumor lines 5563 and 5647, both of which grow in $\mathrm{C}_{3} \mathrm{H}$ mice, were obtained from Dr. Potter. The mammary carcinoma of $\mathrm{C}_{3} \mathrm{H}$ mice was obtained from Dr. J. Craigie, and is maintained at the Imperial Cancer Research Fund Laboratories, Mill Hill. All three tumors are passed by subcutaneous implantation with a trochar, and grow during the course of 8 to 12 weeks to form large nodules, weighing up to $8 \mathrm{~g}$ before metastasis occurs. Tumor-bearing mice are in good general health until the terminal stage and show no renal abnormality. The paper electrophoretic patterns of serum obtained from mice hearing these tumors are illustrated in Figure 1.

Each plasma-cell tumor produces a characteristic protein: the 5563 tumor forms a large amount of $\gamma$-myeloma protein, while the 5647 tumor forms large amounts of $\beta$-myeloma globulin. The physicochemical and immunochemical properties of these myeloma proteins are described in detail elsewhere $(8,9)$. The mammary carcinoma was not associated with any significant changes 
in plasma proteins when examined by paper electrophoresis (Figure 1).

Proteins. Normal mouse $\gamma$-globulin was prepared from the pooled serum of normal adult $\mathrm{C}_{3} \mathrm{H}$ mice or from pooled peritoneal fluid obtained from mice which had been hyperimmunized with hemocyanin (Maia squinado) in Freund's adjuvant $(10,11)$. Zone electrophoresis was carried out on polyvinyl chloride particle blocks (Geon 426) (12), and serial fractions from the $\gamma$-globulin region of each block were individually tested for the presence of $\gamma$-globulin and other serum proteins by the Ouchterlony technique (agar double-diffusion) employing potent rabbit antisera against normal mouse serum proteins and against normal mouse $\boldsymbol{\gamma}$-globulin (9). Those $\gamma$-globulin fractions which were free from contaminating protein were pooled and concentrated by ultrafiltration (13), dialyzed against $\mathrm{pH} 7.4$ sodium phosphate-buffered saline and tested for purity by starch gel electrophoresis and immunoelectrophoresis employing rabbit antinormal mouse serum. At no time in the preparation of the normal mouse $\gamma$-globulin or the 5563 myeloma protein were the fractions frozen.

The 5563 myeloma protein was prepared by the method of Askonas (14). Chromatography of serum containing

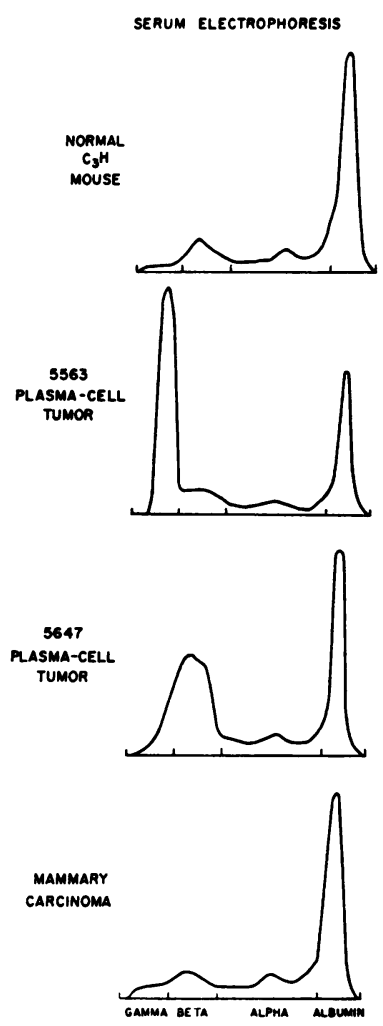

Fig. 1. Serum electrophoretic patterns of mice. Zone electrophoresis under standard conditions (cf Methods) was carried out on paper strips stained by lissamine green and the protein distribution determined by densitometric tracing. approximately $7 \mathrm{~g}$ myeloma protein per $100 \mathrm{ml}$ on columns of diethylaminoethyl (DEAE) cellulose was done (15), employing a gradient elution system (12), with an initial concentration of $0.015 \mathrm{M}$ phosphate in a $\mathrm{pH} 6.5$ potassium buffer and a limit concentration of $0.050 \mathrm{M}$ phosphate while retaining $\mathrm{pH} 6.5$. The central portion of the myeloma protein elution peak was pooled, concentrated, dialyzed and tested in the same manner as the normal serum $\boldsymbol{\gamma}$-globulin.

Mouse albumin was prepared from normal $\mathrm{C}_{3} \mathrm{H}$ mouse serum by Geon block electrophoresis, and selection of the midportion of the albumin zone for concentration and dialysis against buffered saline as described above. The final preparation contained small amounts of a prealbumin and a postalbumin component when tested by starch gel electrophoresis.

Human $\gamma$-globulin was prepared by DEAE-cellulose chromatography of serum from a normal adult male donor. A gradient elution system, starting with a 0.01 $\mathrm{M}$ phosphate, $\mathrm{pH} 8$ buffer, permitted separation of an initial fraction containing only $6.6 \mathrm{~S} \gamma$-globulins (12). No other fractionation procedure (i.e., ethanol) was employed. The starch gel electrophoretic properties of the serum protein fractions are shown in Figure 2.

Iodination with $I^{131}$. Iodination was performed by the iodine monochloride method of McFarlane (16) ; preoxidation with $\mathrm{I}^{127}$ at $\mathrm{pH} 4.6$ was performed in the case of mouse albumin only. The amount of iodine introduced corresponded to 0.2 to 0.5 atom per mole of protein, taken as $160,000 \mathrm{~mol} \mathrm{wt}$ for normal mouse $\gamma$-globulin, 5563 myeloma protein and normal human $\gamma$-globulin, and as $60,000 \mathrm{~mol}$ wt for mouse albumin. About 60 to 80 per cent of the added iodine became attached to protein. After iodination, free iodine was removed by passage through a column of Deacidite-FF in the chloride form (Permutit Co., Ltd., Gunnersbury, England); normal mouse serum was added so that the total radioactivity was less than $10 \mu \mathrm{c}$ per $\mathrm{mg}$ protein, and the mixture was concentrated to a convenient volume by dialysis under pressure against physiological saline buffered at $\mathrm{pH}$ 7.0. The iodinated proteins, mixed with normal mouse serum, were tested by paper electrophoresis and found to have the characteristic electrophoretic mobilities of the parent proteins.

Estimation of radioactivity. Each mouse was housed in a separate cage, and was provided with drinking water containing 0.45 per cent $\mathrm{NaCl}$ and 0.01 per cent $\mathrm{KI}$ in order to accelerate renal excretion of free iodine and to reduce uptake of $I^{131}$ by the thyroid gland to a minimum. Whole-body radioactivity was measured daily or more frequently, in the ring-counter described by Campbell, Cuthbertson, Matthews and McFarlane (17). The whole-body radioactivity was considered to be a good estimate of the retained labeled protein, for 98 to 99.5 per cent of radioactivity in numerous blood samples taken at various times during the tests was present as protein. Radioactivity in plasma samples was measured in a welltype scintillation counter, both before and after precipitation of protein. Protein was precipitated from blood or plasma samples with 10 per cent, wt/vol, trichloroacetic 


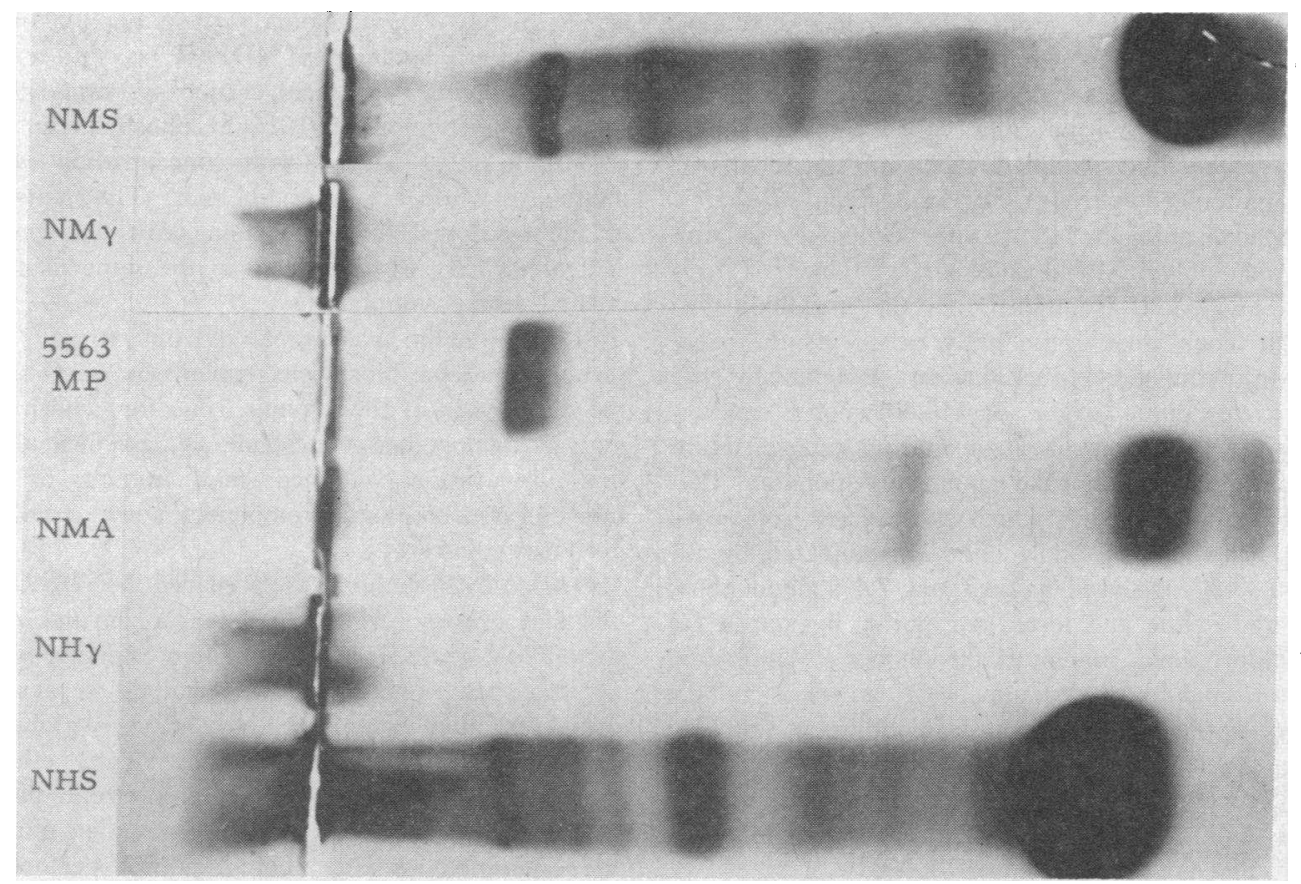

Fig. 2. Starch gel electrophoresis of NORMAL MOUSE SERUM AND SERUM PROTEIN FraCTIONS. Vertical electrophoresis was carried out in $0.03 \mathrm{M}$ Tris borate buffer, $\mathrm{pH} 9.2$, with a discontinuous buffer system $(26,27)$. NMS $=$ normal mouse serum, $\mathrm{NM} \gamma=$ normal mouse $\gamma$-globulin, $5563 \mathrm{MP}=$ myeloma protein from sera of mice bearing the 5563 plasma-cell tumor, $\mathrm{NMA}=$ normal mouse albumin, $\mathrm{NH} \gamma=$ normal human $6.6 \mathrm{~S} \gamma$-globulin, $\mathrm{NHS}=$ normal human serum.

acid. Counting was continued long enough to give an accuracy of at least \pm 3 per cent. All figures were corrected for radioactive decay.

Blood samples during the experiments were taken from the retro-orbital venous plexus under ether anesthesia by a technique similar to that described by Halpern and Pacaud (18). At the end of the experiment the mice were sacrificed and bled out from the heart with a heparinized syringe. The terminal blood samples were used for determination of the hematocrit values. The mice were then weighed (allowance being made for the blood removed) and tumors were excised and weighed separately.

Methods of calculation. Blood volumes were calculated from the radioactivity of blood samples taken 2 to 3 minutes after injection of known amounts of radioactive protein into a tail vein. Plasma volumes were obtained from a knowledge of the blood volumes and the hematocrit values. The ratio of the extravascular to the intravascular plasma protein pools was calculated from the decay curve of plasma protein radioactivity as indicated by Wasserman and Mayerson (19). Approximately $15 \mu \mathrm{c}(1.5 \mathrm{mg})$ of each material to be examined was injected into the tail veins of 4 or more mice. The findings within each group agreed closely except when there was a gross difference in tumor sizes. For this reason mean values are recorded, unless there was a reason for re- cording values individually for each mouse in a group. The half-time was determined from graphic plots of the total body radioactivity corrected for physical decay. The per cent $\mathrm{I}^{131}$-protein degraded per day was obtained by dividing the observed half-time into 0.693 , the natural logarithm of one-half. The quantity of any protein in the circulation (total circulating component), the total amount of exchangeable component, and the quantity of the protein component degraded per day were calculated in the usual way (17).

\section{RESULTS}

\section{Turnover in normal mice}

Mouse albumin. Approximately $15 \mu \mathrm{c}(1.5 \mathrm{mg})$ $\mathrm{I}^{131}$-mouse albumin obtained from $\mathrm{C}_{3} \mathrm{H}$ mice was injected into four normal $\mathrm{C}_{3} \mathrm{H}$ mice weighing 21 to $29 \mathrm{~g}$ (mean $27 \mathrm{~g}$ ). The findings in respect to disappearance of radioactivity from the whole body are illustrated in Figure 3 where labeled albumin was found to have a mean half-life of 1.54 days. Since the plasma radioactivty was 98 to 99 per cent protein-bound at all times in the experiment, the whole-body radioactivity curves can be taken to represent $\mathrm{I}^{131}$-protein catabolism. 


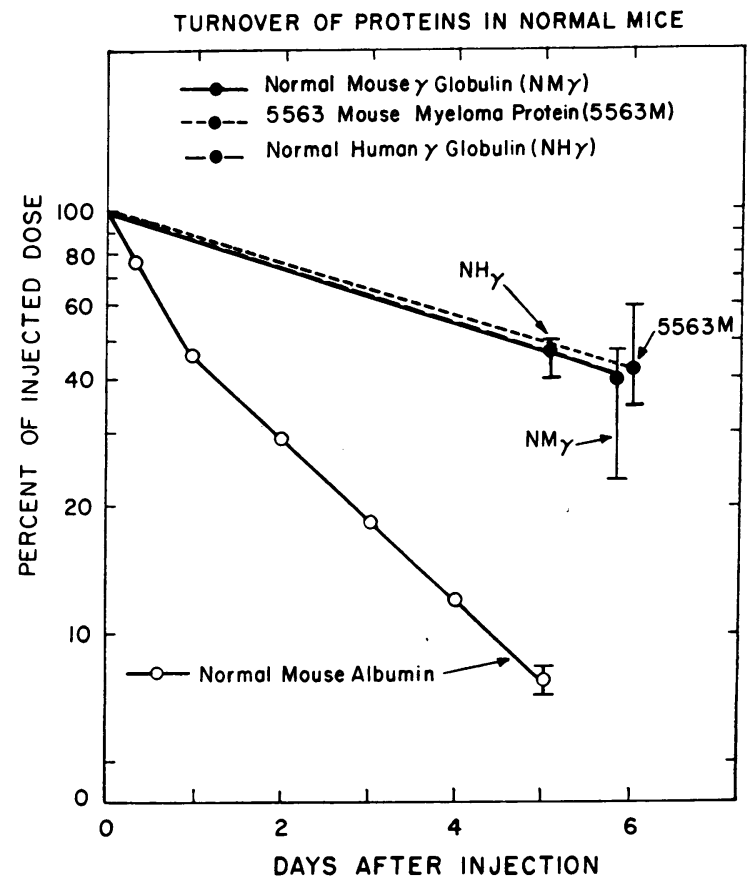

Fig. 3. MEAN elimination of I31-PRoteins inJeCted INTO NORMAL MICE. The range of values indicated by the brackets includes observations in 11 mice $\left(\mathrm{C}_{3} \mathrm{H}\right.$ or $\mathrm{BAlb} / \mathrm{c}$ ) for normal mouse $\gamma$-globulin, 6 mice for human $\gamma$-globulin before immune response, 9 mice for 5563 myeloma protein and 4 mice for normal mouse albumin. Total body radioactivity counts were measured daily, corrected for physical decay and recorded on the ordinate as the per cent of injected dose. Daily mean values fell on the lines and are not shown unless the catabolic curves were not straight lines.

Normal $\gamma$-globulin. I $^{131}$-labeled normal $\mathrm{C}_{: 3} \mathrm{H}$ mouse $\gamma$-globulins were administered to a total of eight normal $\mathrm{C}_{3} \mathrm{H}$ mice in two separate experiments and were found to have a mean half-time of 4.6 days, as shown in Figure 3. The same halftime was observed when $\gamma$-globulin was given to normal $\mathrm{BAlb} / \mathrm{c}$ mice. In order to check that the half-life of the various proteins obtained by wholebody radioactivity was close to their half-life in the plasma, blood samples were examined daily in several tests. Figure 4 shows that the elimination rate for normal mouse $\gamma$-globulin agreed well with that observed by whole-body counting. The mean value for the half-life of normal mouse $\gamma$-globulin observed here is considerably longer than previously reported values (20). Reasons for this are considered in the Discussion.

5563 Myeloma protein. The $5563 \gamma$-myeloma protein was treated by the normal mouse in the same manner as normal mouse $\gamma$-globulin. When injected into eight normal mice the mean was found to be 4.9 days (Figure 3 ). There was no difference in the behavior of 5563 myeloma protein when given to normal $\mathrm{C}_{3} \mathrm{H}$ or $\mathrm{BAlb} / \mathrm{c}$ mice.

Normal human $\gamma$-globulin. Approximately 1.5 $\mathrm{mg}$ of $\mathrm{I}^{131}$ human $6.6 \mathrm{~S} \gamma$-globulin was injected intravenously into five normal $\mathrm{C}_{3} \mathrm{H}$ mice. Since no antibody formed during the first 5 days, it was possible to measure the elimination rate with reasonable accuracy before immune elimination occurred. Only whole-body counts were made in this experiment. It is evident from Figure 3 that normal mice treat human $\gamma$-globulin and mouse $\gamma$-globulin in a similar way, both having a half-life of 4.6 days.

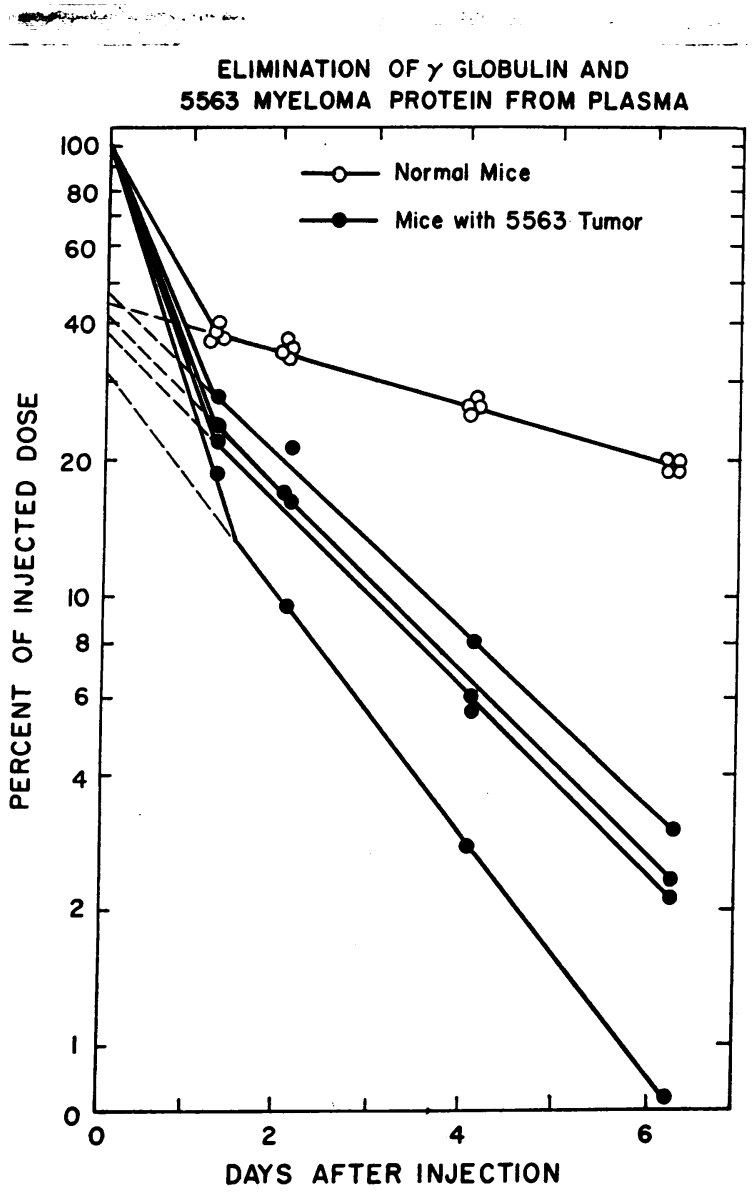

Fig. 4. Elimination of NORMAL MOUSE $\gamma$-GLobUlins AND 5563 MYELOMA PROTEIN FROM THE PLASMA OF 4 NORMAL MICE AND 4 MICE BEARING THE 5563 PLASMA-CELL TUMOR ( 2 MICE OF EACH GROUP FOR ONE PROTEIN). The fraction of the initial isotope concentration in the plasma is recorded on the ordinate. 


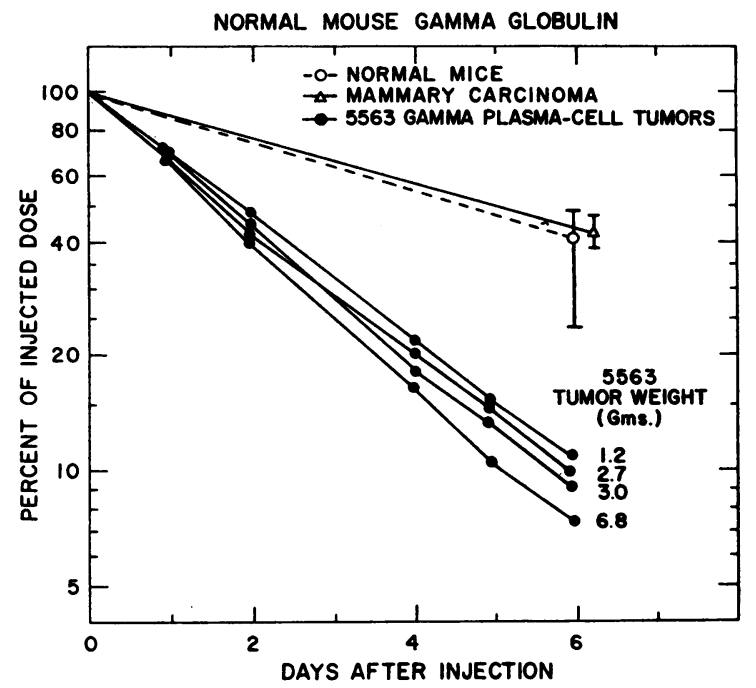

Fig. 5. Elimination of NORMal mouse $\gamma$-Globulin FROM TUMOR-BEARING MICE. The median weight of the mammary carcinoma tumors in 4 mice was $3.3 \mathrm{~g}$.

\section{Turnover in tumor-bearing mice}

5563 Plasma-cell tumor. This tumor, which produces a $\gamma$-myeloma protein (Figure 1 ), caused a striking increase in the turnover of normal mouse $\gamma$-globulin and 5563 myeloma protein (Figures 5 and 6) but no evident alteration in albumin turnover (Figure 7 ). Normal $\gamma$-globulin turnover was measured in four mice which bore tumors with an average weight of $3.4 \mathrm{~g}$. The mean halftime was 1.8 days, compared with 4.6 days in

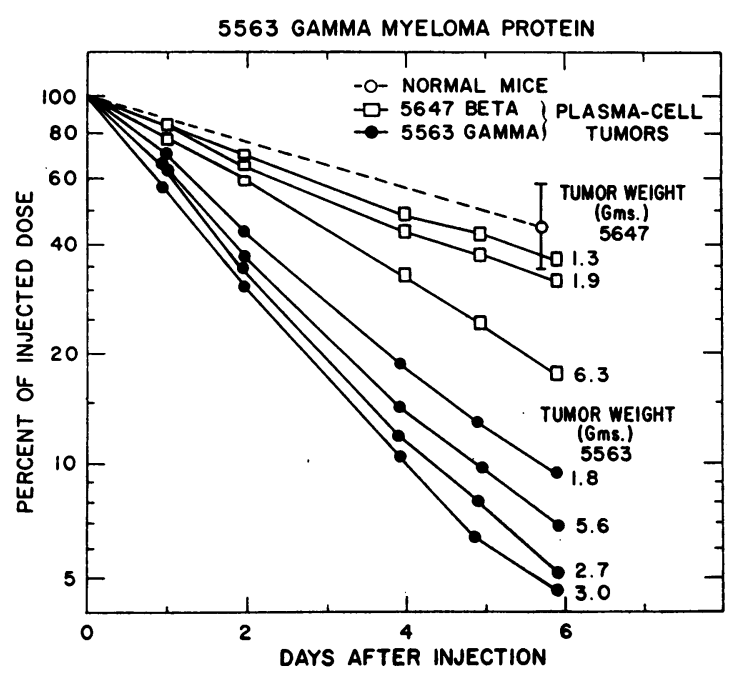

Fig. 6. Elimination of $5563 \gamma$-MYeloma PROTEIN FROM TUMOR-BEARING MICE.

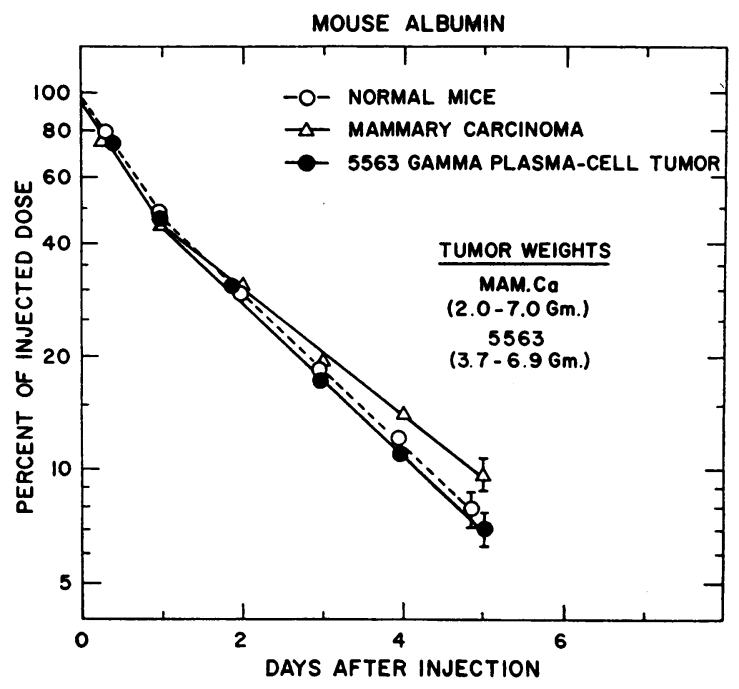

Fig. 7. Elimination of mouse albumin from tUmorBEARING MICE.

normal mice. Even a $1.2 \mathrm{~g}$ tumor, which represented less than 5 per cent of the total body weight, had a profound effect on $\gamma$-globulin turnover (Figure 5).

The turnover of $5563 \gamma$-myeloma protein was also markedly increased by the tumor. A mean half-time of 1.5 days was observed in four mice bearing tumors with an average weight of $3.3 \mathrm{~g}$. The half-life of the various proteins obtained by whole-body counting was checked by measurement of their half-life in the plasma. The data in Figure 4 , showing the elimination of $\mathrm{I}^{131}$-labeled normal mouse $\gamma$-globulin, or 5563 myeloma protein (two in each group of four normal mice and four mice with 5563 plasma-cell tumor), correlate well with the elimination rates determined by wholebody counting.

Albumin turnover, by contrast, was not appreciably altered in four mice bearing 5563 tumors weighing 3.7 to $6.9 \mathrm{~g}$ (mean 4.9). As is shown in Figure 7, the half-time was 1.46 days.

Human $\gamma$-globulin turnover was also measured in four mice with 5563 tumors, as is shown in Figure 8 , and was found to be accelerated (mean half-time 2.8 days) in mice with tumors weighing 3.7 to $6.9 \mathrm{~g}$. This effect, although real, is less marked than that seen with the homologous globulins.

5647 Plasma-cell tumor. This $\beta$-globulin-producing tumor had less effect on $\gamma$-globulin turnover than did the $\gamma$-type plasma-cell tumor (Fig- 


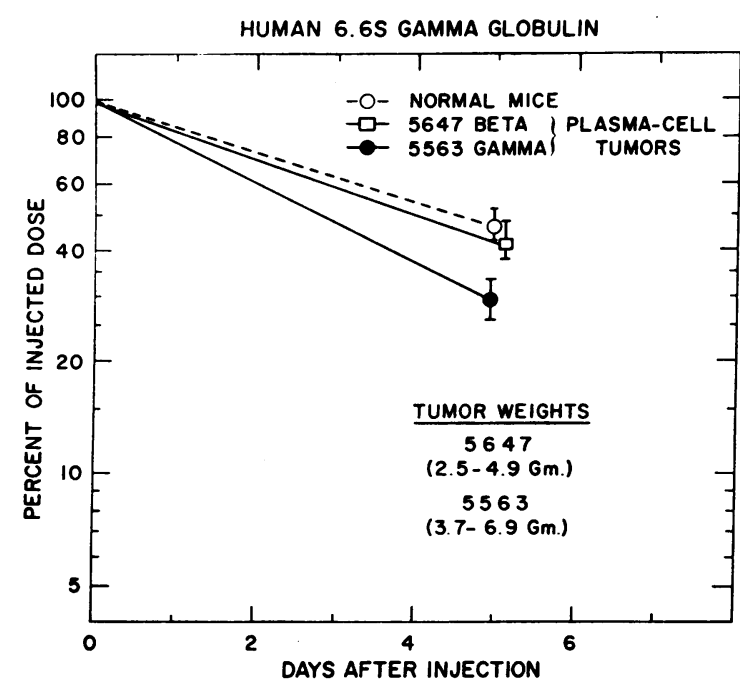

Fig. 8. Elimination of Human 6.6S $\gamma$-GLObUlin fRom TUMOR-BEARING MICE.

ure 6). The $5563 \gamma$-myeloma protein had a mean half-time of 3.8 days in five mice bearing $5647 \mathrm{tu}$ mors weighing 1.3 to $6.3 \mathrm{~g}$ (mean 3.2 ), in contrast to a half-time of 4.9 days in normal mice and to 1.5 days in mice with 5563 tumors of similar size.

Human $\gamma$-globulin turnover was also less markedly affected, the mean half-time being 4.1 days for seven mice with 5647 tumors (Figure 8), compared with 4.6 days in normal mice and 2.8 days in mice with the 5563 tumor. Albumin turnover was not measured.

Mammary carcinoma. This tumor grew at about the same rate as did the plasma-cell tumors but caused no evident change in the plasma proteins. It served as a control for the effects of the presence of malignant tissue per se on plasma protein me- taholism. $A \mathrm{~s}$ is shown in Figure 5, the turnover of mouse $\gamma$-globulin was normal, the mean halftime being 4.8 days in four mice with a mean tumor weight of $3.3 \mathrm{~g}$. Albumin turnover was slightly prolonged, with a mean half-time of 1.9 days in four mice whose tumors weighed 2 to $7 \mathrm{~g}$ (mean 5 ; Figure 7 ).

\section{Rates of protein synthesis}

The intravascular pool of serum protein, determined from the measurements given in Figure 4 , constituted about 45 per cent of the total in the body. In Table I are summarized the values obtained for blood and plasma volume and for the ratio of intravascular to total plasma protein.

Albumin synthetic rate was calculated from the data assembled in Table II. Approximately 116 $\mathrm{mg}$ of albumin is synthesized per $100 \mathrm{~g}$ of mouse weight-i.e., about $29 \mathrm{mg}$ albumin per day for each $25 \mathrm{~g}$ normal mouse. The synthetic rate and the fractional rate of albumin degradation were not markedly altered by the presence of the 5563 plasma-cell tumor. The serum albumin concentration was substantially reduced, however, by a dilutional effect from increased plasma volume and increased extravascular distribution of albumin.

Normal $\gamma$-globulin synthesis was only onetwentieth that of albumin. As is seen in Table II, approximately $5.2 \mathrm{mg}$ of $\gamma$-globulin was synthesized per $100 \mathrm{~g}$ mouse weight, or $1.3 \mathrm{mg}$ per $25 \mathrm{~g}$ mouse.

Presence of the 5563 plasma-cell tumor more than doubled the fractional rate of normal $\gamma$-globulin removal. Calculation of the rate of normal

TABLE I

Effect of tumors on volume of protein distribution

\begin{tabular}{|c|c|c|c|c|c|}
\hline Group & No. & $\begin{array}{l}\text { Range of } \\
\text { tumor } \\
\text { weights }\end{array}$ & Blood volume & Plasma volume & $\begin{array}{l}\text { Approx. ratio. } \\
\text { intravasc. and total } \\
\text { plasma protein }\end{array}$ \\
\hline & & $\begin{array}{l}\text { \% total } \\
\text { body wt }\end{array}$ & $\begin{array}{c}\mathrm{ml} / 100 \mathrm{~g} \\
\text { total wt }\end{array}$ & $\begin{array}{c}\mathrm{ml} / 100 \mathrm{~g} \\
\text { total wil }\end{array}$ & \\
\hline Normal $\mathrm{C}_{3} \mathrm{H}$ & 2 & & $7.0-7.25$ & 3.9 & $1: 2.2$ \\
\hline Normal BAlb/c & 5 & & $6.5-7.5$ & $3.2-3.8$ & $1: 2.2$ \\
\hline $\begin{array}{l}5563 \text { Plasma-cell } \\
\text { tumor }\end{array}$ & 4 & $4-10$ & $6.7-7.6$ & $4.2-5.0$ & $1: 2.2-2.7(2.5)$ \\
\hline $\begin{array}{l}5647 \text { Plasma-cell } \\
\text { tumor }\end{array}$ & 1 & 20 & 9.3 & 5.9 & $1: 2.0$ \\
\hline Mammary carcinoma & 4 & $6-20$ & $9.6-11.2$ & $6.1-7.1$ & not done \\
\hline
\end{tabular}


TABLE II

Comparison of body content, turnover, and synthctic rate of plasma prolcins in normal and tumor-bearing mice *

\begin{tabular}{|c|c|c|c|c|c|c|c|c|c|c|}
\hline & \multicolumn{5}{|c|}{ Normal $\gamma$-globulin } & \multicolumn{3}{|c|}{$\begin{array}{c}5563 \gamma- \\
\text { myeloma } \\
\text { protein }\end{array}$} & \multicolumn{2}{|l|}{ Albumin } \\
\hline & $\begin{array}{c}\text { Normal } \\
\text { nouse }\end{array}$ & 5563 & 3 Tumor & 5647 & Tumor & $\begin{array}{l}\text { Mammary } \\
\text { carcinoma }\end{array}$ & $\begin{array}{l}5563 \\
\text { Tumor }\end{array}$ & $\begin{array}{l}\text { Normal } \\
\text { mouse }\end{array}$ & $\begin{array}{l}5563 \\
\text { Tumor }\end{array}$ & $\begin{array}{l}\text { Mammary } \\
\text { carcinoma }\end{array}$ \\
\hline $\begin{array}{l}\text { Concentration in serum } \\
(\mathrm{g} / 100 \mathrm{ml})\end{array}$ & 0.40 & if $0.20 \dagger$ & if $0.10 \dagger$ & if $0.40 \dagger$ & if $0.20 \dagger$ & 0.50 & 4.8 & 3.0 & 2.0 & 2.8 \\
\hline$T_{\frac{1}{3}}$ & 4.6 & \multicolumn{2}{|c|}{1.8} & \multicolumn{2}{|c|}{$3.8 \dagger$} & 4.8 & 1.5 & 1.54 & 1.46 & 1.9 \\
\hline $\begin{array}{l}\text { Plasma volume } \\
\qquad(\mathrm{ml} / 100 \mathrm{~g} \text { mouse } w t)\end{array}$ & 3.9 & \multicolumn{2}{|c|}{4.6} & \multicolumn{2}{|c|}{5.9} & 6.6 & 4.6 & 3.9 & 4.6 & 6.6 \\
\hline $\begin{array}{l}\text { Ratio total exchangeable: } \\
\text { intravascular protein }\end{array}$ & 2.2 & \multicolumn{2}{|c|}{2.5} & \multicolumn{2}{|c|}{2.0} & $2.2 \dagger$ & 2.5 & 2.2 & 2.5 & $2.2 \dagger$ \\
\hline $\begin{array}{l}\text { Total circulating component } \\
(\mathrm{mg} / 100 \mathrm{~g} \text { mouse } w t)\end{array}$ & 15.6 & 0.2 & 4.6 & 23.6 & 11.8 & 33.0 & 221.0 & 117 & 92 & 185 \\
\hline $\begin{array}{l}\text { Total exchangeable component } \\
\quad(\mathrm{mg} / 100 \mathrm{~g} \text { mouse } w t)\end{array}$ & 34.3 & 23.0 & 11.5 & 47.2 & 23.6 & 72.6 & 553.0 & 257 & 230 & 406 \\
\hline $\begin{array}{l}\text { \% } \text { I }^{131} \text {-protein } \\
\text { degraded/day } \ddagger\end{array}$ & 15 & & 38.5 & \multicolumn{2}{|c|}{18.2} & 14.4 & 46.2 & 45.0 & 46.3 & 36.4 \\
\hline $\begin{array}{l}\text { Amount degraded } \\
\text { a!nount synthesized } \\
(m g / 100 \mathrm{~g} / \text { day })\end{array}$ & 5.2 & 8.9 & 4.4 & 8.6 & 4.3 & 10.5 & 256.0 & 116 & 107 & 148 \\
\hline
\end{tabular}

* Calculated on basis of mean tumor weights of $11.2 \mathrm{~g}$ (5563 tumor), $10.6 \mathrm{~g}$ (5647 tumor), $10.9 \mathrm{~g}$ (mammary carcinoma) and liver weight of $6 \mathrm{~g}$ per $100 \mathrm{~g}$ mouse weight.

$\dagger$ Values based on estimations described in the text.

$\ddagger \% I^{131}$-protein degraded per day $=100\left(1-\frac{0.693}{T_{1}}\right)$.

$\gamma$-globulin synthesis in the presence of this tumor, however, requires an assumption as to the level of the normal $\gamma$-globulin components. The large amount of myeloma protein overshadows much of the $\gamma$-globulin region and prevents quantitative measurement of the normal components, but immunoelectrophoresis and starch gel electrophoresis have shown that normal $\gamma$-globulin components are reduced $(8,9)$. Since such analyses were not susceptible to quantitative assessment, two sets of calculations are made in Table II, based on the assumption that normal $\gamma$-globulin concentrations were in the range of one-half to one-quarter the normal level. If these assumptions are correct, the rate of $\gamma$-globulin synthesis was about normal in the presence of the 5563 tumor.

The $\beta$-globulin-producing 5647 plasma-cell tumor had much less effect on the fractional rate of $\gamma$-globulin removal than the $\gamma$-globulin-producing 5563 tumor, although the mean tumor weights were approximately the same: 3.2 and $3.4 \mathrm{~g}$, respectively. ${ }^{1}$ Difficulties in measuring the level of

\footnotetext{
1 The calculations of the catabolism of normal mouse $\gamma$-globulin in the mice bearing the 5647 tumor are based on the turnover of $\gamma$-myeloma protein administered to these mice. Because of the similarity of normal $\gamma$-globulin and $5563 \gamma$-myeloma protein metabolism in normal and 5563 tumor-bearing mice, it seems reasonable to believe that this will apply also for mice with the 5647 tumor.
}

normal $\gamma$-globulins were encountered also with the 5647 tumor, but qualitative tests indicated that the $\gamma$-globulins were not so markedly reduced with this tumor and, therefore, calculations were made, assuming normal or half-normal $\gamma$-globulin levels. Gamma-globulin synthesis, as shown in Table II, appeared to be normal in the presence of this tumor.

Gamma-globulin levels were slightly elevated by the presence of the mammary carcinoma, perhaps because some of the tumors were partially necrotic. The fractional rate of $\gamma$-globulin removal was normal with these tumors (Table II), although the rate of $\gamma$-globulin synthesis appeared to be increased.

The 5563 myeloma protein was very rapidly degraded in the presence of the 5563 tumor, almost half of the protein being removed and replaced per day. The rate of 5563 myeloma globulin synthesis was calculated to be approximately $19 \mathrm{mg}$ protein per $\mathrm{g}$ tumor per day.

\section{DISCUSSION}

The catabolic behavior of $\gamma$-globulin differed notably from that of albumin in the mouse. The half-life of 4.6 and 1.5 days for these two proteins differs considerably and, in this feature, stands apart from the usual finding in species other than 
rudents (20). The mean half-life of 4.6 days for normal mouse $\gamma$-globulin is longer than the 1.9 days previously reported (20). The reason for this may be that the materials which we used were prepared and iodinated by techniques that more effectively avoided denaturation, or that the $\gamma$-globulin used in previous reports contained other serum globulins, since uncontaminated $\gamma$-globulins are difficult to obtain from mouse serum. In this connection it is worth noting that the $\gamma$-globulins tested in the present study had antibody activity and were isolated by preparative electrophoresis with care, in order to obtain only uncontaminated $\gamma$-globulin fractions. The $\gamma$-globulins were not frozen after purification, and iodination was carried out with a molecular ratio for iodine: $\gamma$-globulin of $1: 2$ or less.

The factors controlling catabolism of normal $\gamma$-globulins and other serum proteins are unknown. Campbell and co-workers (17) studied the behavior of separately labeled albumin and $\gamma$-globulin in the rabbit and rat and concluded, because of differences in urinary and plasma specific activity curves, that these two proteins were metabolized by independent processes. This view has been confirmed in the present studies where $\gamma$-globulin catabolism was accelerated by a plasma-cell tumor without any effect on albumin catabolism.

Differences in the metabolic effects of individual lines of malignant plasma cells were clearly evident. The $\beta$-globulin-producing 5647 mouse tumor had a less marked effect than had the 5563 tumor. This difference in effect between the two plasma-cell tumors is in agreement with the observations of Lippincott and colleagues (3) that normal $\gamma$-globulin turnover was greater in patients with $\gamma$-myeloma proteins than in those with $\beta$-myeloma proteins.

Inasmuch as catabolism of plasma proteins occurs predominantly or exclusively in close association with the blood stream $(17,21)$ a possible explanation for the differences observed might be available if the ratio of intra- to extravascular protein were much increased in mice with 5563 tumors. This was not found to be the case. Another possibility would be that $\gamma$-globulins were being lost through the glomeruli, and broken down during reabsorption by the renal tubules; but mice bearing the 5563 tumor do not show renal abnormalities or increased proteinuria. The remaining alternatives appear to be that either the presence of $5563 \gamma$-myeloma protein as such, or the presence of the tumor, is responsible in some other way.

It is not clear, however, that a simple gross increase in $\gamma$-globulin level is entirely responsible for the increased rate of $\gamma$-globulin destruction. Although, in general, mice with the highest levels of 5563 myeloma protein had the highest $\gamma$-globulin elimination rates, the correlation was not complete nor was there any simple relationship between the two. Even the mice with a $1.2 \mathrm{~g}$ tumor showed elimination rates 2.1 times normal, while those with the largest neoplasm ( $6 \mathrm{~g})$ were 2.9 times normal. Sufficient 5563 myeloma protein was not available to test directly the effect of maintaining high plasma levels of this protein in the absence of a neoplasm. It seems unlikely that the presence of the protein is the entire explanation, since Humphrey and McFarlane (22) found that rabbits, with $\gamma$-globulin increased to 4 times normal levels by hyperimmunization, had the same fractional rate of $\gamma$-globulin removal as had normal rabbits. The mouse with a $1.2 \mathrm{~g} 5563$ plasmacell tumor had a comparable increase of his total $\gamma$-globulins but the rate of $\gamma$-globulin removal was markedly increased.

It is interesting that the catabolic behavior of the $5563 \gamma$-myeloma protein and of normal mouse $\gamma$-globulin was similar in all groups of mice in which comparison was made, although the finding is perhaps not surprising in view of the physicochemical and immunological resemblance of the proteins. More unexpected is the similarity in rate of removal and catabolism of human and rabbit (20) $\gamma$-globulin to mouse $\gamma$-globulins, their half-life in mice being almost the same. Whatever the factors that determine their catabolic rate, it is apparent that there are some relevant differences between mouse and human $\gamma$-globulin molecules, since the presence of the 5563 plasma-cell tumor caused a greater increase in the rate of turnover of the one than of the other.

In view of the evidence that myeloma proteins in both mouse and man can be classified into two major groups, the $\gamma$-type and $\beta$ (or $\beta_{2 \mathrm{~A}}$ )-type myeloma proteins ( 8$)$, and because of the physicochemical and immunochemical differences between these groups, a comparison of the metabolic 
behavior of representative proteins from these two groups would be important. Although it was not possible to carry out a thorough comparison, in the course of the present work preliminary studies were undertaken with a $\beta$-type myeloma protein associated with the MPC-2 plasma-cell tumor of $\mathrm{BAlb} / \mathrm{c}$ mice (23). The half-life in normal mice of this $\beta$-myeloma protein was much shorter (about 1 day) than that noted above for a $\gamma$-myeloma globulin. In the case of the MPC-2 myeloma protein, however, some denaturation had almost certainly occurred in preparation, and the true value may be somewhat greater. The MPC-2 tumor also produces a urinary Bence Jones protein (23). When the Bence Jones protein was labeled and injected intravenously, plasma and whole-body radioactivity fell very rapidly, virtually all having been eliminated in 24 hours. Approximately 30 per cent of the radioactivity in the urine was bound to protein, presumally in the form of unchanged Bence Jones protein.

The 5563 myeloma protein was synthesized in vivo at the rate of $19 \mathrm{mg}$ protein per $\mathrm{g}$ (wet weight) of plasma-cell tumor per day. This figure determined by $\mathrm{I}^{131}$ turnover studies may be compared with the value of $14 \mathrm{mg}$ per $\mathrm{g}$ tumor per day estimated in studies of the turnover of protein labeled with $\mathrm{C}^{14}$-lysine in vivo (24). Askonas (14), however, has shown that 5563 tumor slices form protein at a slower rate in vitroi.e., 1.5 to $2 \mathrm{mg}$ per $\mathrm{g}$ tumor per day, approximately one-tenth the in vir'o rate.

Synthesis of 5563 myeloma protein occurs as rapidly in the plasma-cell tumor as does synthesis of albumin in mouse liver, which also forms approximately $19 \mathrm{mg}$ albumin per $\mathrm{g}$ tissue each day.

Low serum albumin levels, a common feature of malignant disease in man, were found in the animals bearing the tumors used in the present study. Steinfeld (25) studied the turnover of albumin in 12 patients with neoplastic disease and found that the percentages of body albumin degraded and synthesized per day were abnormal except in the one patient with multiple myeloma. Neufeld (5) reported a normal half-time for albumin in two patients with myeloma. Similarly in mice, the mammary carcinoma depressed the percentage of albumin degraded and synthesized per day, although the 5563 mouse plasma-cell tumor did not have this effect. Speculation on the significance of a difference between the effects of carcinomatous and plasma-cell malignancies on albumin metabolism, however, should await further study.

\section{SUMMARY}

Transplantable plasma-cell tumors in mice closely resemble multiple myeloma in man, and both result in decreased serum levels of normal $\gamma$-components and of albumin, in the presence of large amounts of myeloma protein.

The metabolism of normal mouse $\gamma$-globulin, of a mouse $\gamma$-myeloma protein, of normal human $\gamma$-globulin, and of mouse albumin was studied in normal mice or tumor-bearing mice by means of purified proteins labeled with $\mathrm{I}^{131}$.

The tumors were a $\gamma$-type (5563) plasma-cell tumor, a $\beta$-type (5647) plasma-cell tumor, and a mammary carcinoma with similar growth characteristics.

In normal mice the half-time for the turnover of all three $\gamma$-globulins was 4.6 days, while the half-time for allomin was 1.54 days.

The $\gamma$-type plasma-cell tumor caused a very marked acceleration of $\gamma$-globulin catabolism, while the $\beta$-type tumor had much less, and the mammary carcinoma no such effect. Neither in normal nor in tumor-bearing mice was there any difference between the behavior of $\gamma$-myeloma globulin and of normal $\gamma$-globulin.

In normal mice about 20 times more albumin than normal $\gamma$-globulin was synthesized each day. The synthesis of normal $\gamma$-globulin and of albumin was unaltered by the presence of the plasma-cell tumor.

The 5563 plasma-cell tumor synthesized about $19 \mathrm{mg}$ of myeloma protein per $\mathrm{g}$ wet weight per day. This rate is at least as great as that of albumin synthesis in the liver.

\section{REFERENCES}

1. Potter, M., and Fahey, J. L. Studies on eight transplantable plasma-cell neoplasms of mice. J. Nat. Cancer Inst. 1960, 24, 1153.

2. Berson, S. A., and Yalow, R. S. Serum protein turnover in multiple myeloma. J. Lab. clin. Med. 1957, 49, 386.

3. Lippincott, S. W., Korman, S., Fong, C., Stickley, E., Wolins, W., and Hughes, W. L. Turnover of labeled normal gamma globulin in multiple myeloma. J. clin. Invest. 1960, 39, 565. 
4. Lippincott, S. W., Korman, S., and Hughes, W. L. Turnover of autologous and homologous labeled globulin in multiple myeloma. Submitted for publication.

5. Neufeld, A. H. A new concept of the metabolism of the pathological proteins in myelomatosis. Canad. J. Biochem. 1957, 35, 977.

6. Potter, M., Fahey, J. L., and Pilgrim, H. I. Abnormal serum protein and bone destruction in transmissible mouse plasma cell neoplasm (multiple myeloma). Proc. Soc. exp. Biol. (N. Y.) 1957, 94, 327.

7. Fahey, J. L., Potter, M., Gutter, F. J., and Dunn, T. B. Distinctive myeloma globulins associated with a new plasma cell neoplasm of strain $\mathrm{C}_{3} \mathrm{H}$ mice. Blood 1960, 15, 103.

8. Fahey, J. L. Immunochemical studies of 20 mouse myeloma proteins: Evidence for two groups of proteins similar to gamma and beta $2 \mathrm{~A}$ globulins in man. J. exp. Med. In press.

9. Fahey, J. L. Physiochemical characterization of mouse myeloma proteins. Demonstration of heterogeneity for each myeloma globulin. J. exp. Med. In press.

10. Freund, J., and McDermot, K. Sensitization to horse serum by means of adjuvants. Proc. Soc. exp. Biol. (N. Y.) 1942, 49, 548.

11. Munoz, J. Production in mice of large volumes of ascites fluid containing antibodies. Proc. Soc. exp. Biol. (N. Y.) 1957, 95, 757.

12. Fahey, J. L., and Horbett, A. P. Human gamma globulin fractionation on anion exchange cellulose columns. J. biol. Chem. 1959, 234, 2645.

13. Sober, H. A., Gutter, F. J., Wyckoff, M. M., and Peterson, E. A. Chromatography of proteins. II. Fractionation of serum proteins on anion-exchange cellulose. J. Amer. chem. Soc. 1956, 78, 756.

14. Askonas, B. A. A study of globulin formation by a mouse transplantable plasma cell neoplasm (5563). Biochem. J. 1961, 79, 33.

15. Peterson, E. A., and Sober, H. A. Chromatography of proteins. I. Cellulose ion-exchange adsorbents. J. Amer. chem. Soc. 1956, 78, 751.
16. McFarlane, A. S. Efficient trace-labelling of proteins with iodine. Nature (Lond.) 1958, 182, 53.

17. Campbell, R. M., Cuthbertson, D. P., Matthews, C. $\mathrm{M}$., and McFarlane, A. S. Behavior of ${ }^{14} \mathrm{C}$ and ${ }^{131} \mathrm{I}-$ labelled plasma proteins in the rat. Int. J. appl. Radiat. 1956, 1, 66.

18. Halpern, B. N., and Pacaud, A. Technique de prélèvelent d'echantillons de sang chez les petits animaux de laboratoire par ponction du plexus ophthalmique. C. R. Soc. Biol. (Paris) 1951, $145,1465$.

19. Wasserman, K., and Mayerson, H. S. Exchange of albumin between plasma and lymph. Amer. J. Physiol. 1951, 165, 15.

20. Weigle, W. O. Elimination of $\mathrm{I}^{131}$ labelled homologous and heterologous serum proteins from blood of various species. Proc. Soc. exp. Biol. (N. Y.) 1957, 94, 306.

21. Berson, S. A., and Yalow, R. S. The distribution of $\mathrm{I}^{131}$ labeled human serum albumin introduced into ascitic fluid: Analysis of the kinetics of a three compartment catenary transfer system in man and speculations on possible sites of degradation. J. clin. Invest. 1954, 33, 377.

22. Humphrey, J. H., and McFarlane, A. S. Rate of elimination of homologous globulins (including antibody) from the circulation. Biochem. J. 1954, $57,186$.

23. Fahey, J. L., and Potter, M. Bence Jones proteinuria associated with a transplantable mouse plasmacell neoplasm. Nature (Lond.) 1959, 184, 654.

24. Nathans, D., Fahey, J. L., and Potter, M. The formation of myeloma protein by a mouse plasma cell tumor. J. exp. Med. 1958, 108, 121.

25. Steinfeld, J. L. $\mathrm{I}^{131}$ albumin degradation in patients with neoplastic diseases. Cancer 1960, 13, 974.

26. Smithies, O. An improved procedure for starch-gel electrophoresis: Further variations in the serum proteins of normal individuals. Biochem. J. 1959, 71, 585.

27. Poulik, M. D. Starch gel electrophoresis in a discontinuous system of buffers. Nature (Lond.) 1957, 180, 1477. 